\title{
Impacts of Climate Change on Fish Production among Rural Fishing Households in Delta State, Nigeria
}

\author{
Emaziye, P.O \\ Department of Agricultural Economics and Extension, Faculty of Agriculture, Delta State University, Asaba \\ Campus, Asaba, Delta State, Nigeria
}

\begin{abstract}
The major aim of the study was to examine the climatic impacts on rural fishing households. Data were obtained with the aid of structured questionnaires and analysed using descriptive statistics and the chi-square analysis model. Multi-stage sampling techniques were adopted in the purposive selection of 45 rural fishing households. Most respondents were aged with large household size and male-headed households. Respondents were mostly married to a secondary school level of education. Respondents were dominated with low annual income indicating poverty which resulted from climatic effects. Flooding was severe that destroyed the rural fishing business resulting in critical climatic impacts. Short term relief measures should be given by the government and donor agencies to easy to agonies of rural fishing households.
\end{abstract}

Keywords: Climate change, fish, impacts, households production

\section{INTRODUCTION}

The word climate change refers to the changes in the climate of the earth globally within a period of 30 years ranging from 30 years to millions of years (Ikeme, 2001). The international panel of climate change postulated that climate change is caused by human activities accounted for about $90-95$ percent.

Climate and environmental alterations had led to an alteration in the biophysical life aided system which includes vegetation, soil, atmosphere and water resources that give life long-term earth sustainability (Emaziye, 2013). Climate change impacts on freshwater $\left(\mathrm{H}_{\mathrm{a}} 0\right)$ resources had a significant impact on water availability for agriculture and domestic (Emaziye, 2013). Climate change impacts change caused by human activities and natural climate cycles have negatively affected agricultural outputs in Africa (Ziervogel et al., 2006). Asia and SubSahara Africa especially Nigeria with a high population that denied their living from Agriculture, and agricultural lands been flooded and degraded what will be their survival rate (Ilo, 2007).

This is a serious situation that needs an urgent answer and attention. FAO (2008) stated that if agricultural production in Asia and developing countries with low-income were seriously affected by climate change factors, resulting in rural poor household food insecurity.

Hoeppe and Currenko (2006) reported that floods, droughts and storms that are increasing were major causes of economic losses in the agricultural sector. IFAD (2010) also observed that if mitigation measures are not adopted crop outputs of Agriculture in Africa will be reduced by 50 percent.

Eurofish International Organization (2010) reported that climate change is having a serious impact on fish survivals in the ocean since there is the sea temperature in or ease, a melting of polar ice, acidifying of water bodies and reduction low-oxygen 
content resulting to fish stock stress and immigration. The absorption of oxygen in warm water especially in the open sea is usually reduced as a result of climate change that causes sea-level rise. Acidification of the ocean and rising ocean temperature are seriously changing the marine aquatic ecosystem (Doney (2006), IPCC, 2007). Freshwater ecosystems are being affected by alterations in water flow, water temperature resulting to fish habitat loss fish distribution modification and productivity of freshwater species and marine (Cheung et al., 2009).

Climate change has led to the vulnerability of countries' fish producers and countries dependent on fish production (Allison et al., 2009). Fishing population variables such as stability, utilization, access and availability are been altered by climate change (Garcia (2010). Climate change had led to sea-level rise resulting in temperature increase and low-oxygen content in seawater which can lead to aquatic animals' extinction (Portner and Knust, 2007).

This situation is a serious concern to poorest counties nutrition as about three billion persons depend on the fish protein (World Fish Centre, 2008).

Does this research study tend to address the research gap of what are the levels of climatic impacts on fishing households? Also, other research questions are given below.

i. What are the socio-economic characteristics of rural fishing households.

ii. What are the annual income level of the respondents

iii. What are the effects of climate change on rural fishing households.

\section{Hypothesis}

The following hypothesis was tested:

Haci: There was no statistically significant difference between the climatic impacts on the rural fishing household.

Haci: There was a statistically significant difference between the climatic impacts on rural fishing households.

\section{The objective of the study}

The objective of the study was to:

i. examine the socio-economic characters of rural fishing households.

ii. analyse the annual income level of rural fishing households.

iii. Iii evaluates the effects of climate change on rural fishing households.

iv. examine the climate and environmental factors that affect rural fishing households.

v. determine the climate impacts level on rural fishing households.

\section{METHODOLOGY \\ Study Area}

Delta State is among the states that make up the Niger Delta Region, Nigeria. It has 25 Local Government Areas with diverse ethnic nationalities namely, Isokos, Urhobos, Itsekiris, Aniomas, Kwales and Ijaws. The area has a land area of 16,842 $\mathrm{km}^{2}$ and a population of $4,112,445$ persons (National Population Commission (2006). Delta State lies between latitude $5^{\circ} 00^{\prime}$ and $6^{\circ} 45^{\prime} \mathrm{E}$ and longitude $5^{\circ} 00^{\prime}$ and $6^{\circ} 30^{\prime} \mathrm{N}$. Delta State has a plain topography with a wide coastal-belt. That inter-lace with streams and rivulets which constitute the River Niger. The main occupation of the area is agriculture.

\section{Sampling}

Multi-stage sampling procedures were used in the purposive collection of 45 rural fishing households utilized for the study. Firstly, five Local Government Areas were purposively selected due to constant adverse climatic factors such as flooding presence in the Local Government Areas. Secondly, three rural communities each were randomly selected to give a total of 15 communities and lastly was the purposive selection of three rural fishing households given a total of 45 rural fishing households.

\section{Data collection and Analysis}

Data were obtained with aid of structured questionnaires and analyzed using descriptive statistics such as mean, 
Emaziye, P.O. Impacts of climate change on fish production among rural fishing households in Delta State, Nigeria.

mode, tables, frequencies and percentages. Also, the chi-square analysis model was used in the analyzing of climatic impacts on rural fishing households.

\section{Specification of models}

$\ddot{X}=\frac{\Sigma f x}{\Sigma f}$
$X_{\mathrm{ci}}^{2}=\frac{\left(f \circ_{c i}-f e_{c i}\right)^{2}}{f a c i}$
$V=K-1$
$\ddot{X}=$ mean
$F=$ frequency
$X=$ mean mark
$\Sigma=$ summation sign
$\mathrm{X}_{\mathrm{ci}}^{2}=$ chi-square test on climatic impacts on
rural fishing households
fo $\mathrm{c}_{\mathrm{ci}}=$ observed frequency on the climatic
impacts on rural fishing households
fe
impacts on rural fishing households
$\mathrm{V}=$ degree of freedom
$\mathrm{K}=$ categories of the climatic impacts

\section{RESULTS AND DISCUSSION \\ Socio-economics characteristics of rural fishing households}

The rural fishing households average age was 47 years with a household size of 11 persons indicating a large household size. Most rural fishing households were married $(60.0 \%)$ and male gender household heads dominated the area of study. Most respondents had a secondary school level of education $(42.2 \%)$ while no formal educational level $(7.0 \%)$ and tertiary educational levels $(04 \%)$ were least as shown in Table 1. These findings were similar to Emaziye (2020) who reported that most faring operations namely crops, livestock and fisheries production were left in the hand of aged persons with a low level of education and large household size in rural households in Delta State, Nigeria.

\begin{tabular}{|c|c|c|c|}
\hline Socio-economic characteristics & Frequency & Percentage (\%) & Mean/mode \\
\hline $\begin{array}{l}\text { Age in years } \\
24-36 \\
37-49 \\
50-62 \\
63-75\end{array}$ & $\begin{array}{l}8 \\
18 \\
16 \\
3\end{array}$ & $\begin{array}{l}17.8 \\
40.0 \\
35.5 \\
6.7\end{array}$ & 47 years \\
\hline $\begin{array}{l}\text { Household Size (persons) } \\
4-6 \\
7-9 \\
10-12 \\
13-15\end{array}$ & $\begin{array}{l}2 \\
10 \\
16 \\
17\end{array}$ & $\begin{array}{l}4.4 \\
22.2 \\
35.6 \\
37.8\end{array}$ & 11 persons \\
\hline $\begin{array}{l}\text { Marital Status } \\
\text { Married } \\
\text { Single } \\
\text { Widow } \\
\text { Divorced } \\
\end{array}$ & $\begin{array}{l}27 \\
0 \\
12 \\
6 \\
\end{array}$ & $\begin{array}{l}60.0 \\
00.0 \\
26.7 \\
13.3\end{array}$ & Married \\
\hline $\begin{array}{l}\text { Gender } \\
\text { Male } \\
\text { Female }\end{array}$ & $\begin{array}{l}32 \\
13\end{array}$ & $\begin{array}{l}71.1 \\
28.9\end{array}$ & Male \\
\hline $\begin{array}{l}\text { Education level } \\
\text { No formal education } \\
\text { Primary education } \\
\text { Secondary education } \\
\text { Tertiary education }\end{array}$ & $\begin{array}{l}7 \\
15 \\
19 \\
04\end{array}$ & $\begin{array}{l}15.6 \\
33.3 \\
42.2 \\
08.9\end{array}$ & Secondary education \\
\hline
\end{tabular}

\section{Annual income level of rural fishing households}

Table 2: Annual income level of rural fishing households

\begin{tabular}{|c|c|c|c|}
\hline Income (N) & Frequency & Percentage (\%) & Mode \\
\hline $11,000-22,000$ & 06 & 13.3 & \\
\hline $23,000-34,000$ & 12 & 26.7 & \\
\hline $35,000-46,000$ & 14 & 31.1 & $\sharp 38,633.33$ \\
\hline $47,000-58,000$ & 09 & 20.0 & $(\$ 80.5)$ \\
\hline $59,000-70,000$ & 04 & 8.9 & \\
\hline
\end{tabular}

The respondents annual income level as shown in Table 2 revealed that $\$ 11,000$ $\$ 22,000 \quad(13.3 \%), \quad \$ 23,000-\$ 34,000$ (26.7\%), $\$ 35,000-\$ 46,000 \quad(31.1 \%)$, $\$ 47,000$ - $\$ 58,000(20.0 \%)$ and $\$ 59,000-$ $\$ 70,000$ with a mean annual income of $\$ 38,633.33$ ( $\$ 80.5$ ). This is $\$ 105.84$ per day which is $\$ 0.22$ per day for less than the $\$ 1$ per day poverty line index. This clearly 
Emaziye, P.O. Impacts of climate change on fish production among rural fishing households in Delta State, Nigeria.

shown that fish farming was greatly affected and rural fishing households remain poor. This collaborated with the work of Emaziye (2013) that rural households' annual income was $\$ 54,702$ (\$353) indicating low annual income.

\section{Effects of climate change on rural fishing households}

Table 3: Effects of climate change on rural fishing households

\begin{tabular}{|l|l|l|l|}
\hline Effects & Frequency & $\begin{array}{l}\text { Percentage } \\
(\%)\end{array}$ & Mode \\
\hline Lost of fishes & 41 & 14.4 & \\
\hline Lost of homes & 33 & 11.6 & \\
\hline Lost of properties & 40 & 14.0 & \\
\hline $\begin{array}{l}\text { Lost of accessible } \\
\text { roads }\end{array}$ & 38 & 13.3 & \\
\hline $\begin{array}{l}\text { Lost of processing } \\
\text { and storage facilities }\end{array}$ & 21 & 7.4 & \\
\hline Lost of investments & 37 & 13.0 & of \\
\hline Lost of farmsteads & 31 & 10.9 & income \\
\hline Loss of income & 43 & 15.1 & \\
\hline Lost of lives Multiple responses observed & \\
\hline \multicolumn{4}{|l|}{ Source: Field data } \\
\hline
\end{tabular}

The study parameters of the effects of climate change on rural fishing households as shown in Table 3 were diversified as rural fishing households experienced the loss of fishes $(14.4 \%)$, loss of homes $(11.6 \%)$, loss of properties $(14.0 \%)$, lost of the access road (13.3\%), lost of investments (13.0\%), lost of farmsteads $(10.9 \%)$, lost of income $(15.1 \%)$ and lost of live $(0.3 \%)$. Most respondents their incomes were invested in the fishing business. This collaborated with the findings of Han-Otto and Myron (2010) that fish farmers were seriously affected negatively which led to income losses and the collapse of fisheries business.

\section{Climatic and environmental factors affecting rural fishing households}

Table 4: Climatic and environmental factors affecting rural fishing households

\begin{tabular}{|l|l|l|l|}
\hline Factors & Frequency & Percentage (\%) & Mode \\
\hline Flooding & 39 & 32.5 & Flooding \\
\hline Erosion & 28 & 23.3 & \\
\hline Pollution & 30 & 25.0 & \\
\hline Drought & 0 & 00.0 & \\
\hline Thunderstorms & 23 & 19.2 & \\
\hline \multicolumn{4}{|c|}{ Source: Field data, Multiple Responses observed }
\end{tabular}

The parameters in Table 4 revealed that flooding $(32.5 \%)$, erosion $(23.3 \%)$, pollution $(25.0 \%)$ and thunderstorms $(19.2 \%)$ were the climatic and environmental factors that affected the rural fishing households while drought was not a factor recorded in the study area. The most critical factor was flooding that overflown fish ponds resulting in a loss of investment and income. Another major issue was environmental pollution that led to fish poison and death. These reports collaborated with the findings of Emaziye (2015) that agricultural production was inhibited by flooding that destroyed farm produce in the Bayelsa State of Nigeria.

\section{Climatic impacts on rural fishing households}

The impacts were classified into three main categories namely less critical, critical and highly critical. For most rural fishing households climatic impacts were critical (44.4\%). This was a serious concern to the growing population that needs protein for body maintenance as a result of flooding that destroyed the fishing business rendering fish farmers homeless and poor. This is in agreement with Emaziye (2013) that rural farming households experienced moderately food insecure as a result of flooding.

Table 5: Climatic impacts on rural fishing households

\begin{tabular}{|l|l|l|l|}
\hline Impacts & Frequency & Percentage (\%) & Mode \\
\hline Less critical & 9 & 20.0 & \\
\hline Critical & 20 & 44.4 & Critical \\
\hline Highly critical & 16 & 35.6 & \\
\hline \multicolumn{2}{|c|}{ Source: Field data }
\end{tabular}

Table 5: Climatic impacts on rural fishing households

\begin{tabular}{|c|c|c|c|c|c|}
\hline Impacts & $\mathbf{F o}_{\mathbf{i}}$ & $\mathbf{F e}_{\mathbf{i}}$ & $\begin{array}{l}\mathbf{F o}_{\mathbf{i}^{-}} \\
\mathrm{Fe}_{\mathbf{i}} \\
\end{array}$ & $\begin{array}{l}\left(\mathbf{F o}_{\mathrm{i}^{-}}\right. \\
\left.\mathbf{F e}_{\mathrm{i}}\right)^{{ }^{2}}\end{array}$ & $\begin{array}{l}\left(\mathrm{Fo}_{\mathrm{i}^{-}}\right. \\
\left.\mathrm{Fe}_{\mathrm{i}}\right)^{2} / \mathrm{Fe}_{\mathrm{i}}=\mathrm{X}_{\mathrm{i}}^{2}\end{array}$ \\
\hline Less critical & 9 & 15 & -6 & 36 & 2.4 \\
\hline Critical & 20 & 15 & 5 & 25 & 1.7 \\
\hline $\begin{array}{l}\text { Highly } \\
\text { critical }\end{array}$ & 16 & 15 & 1 & 1 & 0.07 \\
\hline Total & 45 & 45 & 0 & 62 & 4.17 \\
\hline
\end{tabular}

\section{Hypothesis test}

$\mathrm{Ho}_{\mathrm{i}}=$ There were no statistically significant differences between climatic impacts on rural fishing households 
Emaziye, P.O. Impacts of climate change on fish production among rural fishing households in Delta State, Nigeria.

$\mathrm{Ha}_{\mathrm{i}}=$ There were statistically significant differences between climatic impacts on rural fishing households.

\section{Decision Rule}

Reject if chi-square calculated > chisquare tabulated

Accept if chi-square calculated < chi-square tabulated

The chi-square calculated in table 6 shown that the less critical calculated chisquare was 2.4 , critical was 1.7 and highly critical was 0.07 while the summation calculated chi-square was 4.17. All the calculated chi-square was less than the tabulated chi-square (10.6) at a 0.005 level of significance and 2 degrees of freedom. The results obtained clearly indicate that the alternate hypothesis can be accepted since the chi-square calculated (4.17) is less than the chi-square tabulated (10.6). So there were statistically significant differences between climatic impacts on rural fishing households in Delta State, Nigeria.

\section{CONCLUSION AND \\ RECOMMENDATION}

Most respondents were aged with large household size and male-headed households. Married rural households and a secondary level of education dominated the study area. There was low annual income indicating poverty. There were various forms of climatic effects on rural fishing households but a loss of income was most critical. The climatic and environmental impacts most severe was flooding that destroyed the fishing business resulting in critical climatic impacts on respondents. Short term relief measures should be given by the government and donor agencies to ease the agonies of rural fishing households.

\section{Acknowledgement: None}

Conflict of Interest: None

Source of Funding: None

\section{REFERENCES}

1. Allisison E.H.A.L. Perry, M-C Badject W.N Adger K. Brown, D. Conway, A.S Halls, G.M. Pilling, J.D. Reynolds, N.L. Andrew and N.K. Dulvy (2009). "Vulnerability of national economies to the impacts of climate change of fisheries Blackwell Publishing Ltd.

2. Cheung, W.W.L., V.I.N T. Lam, J.L. Sarmieto, K. Kearnay, R. Watson, and D. Pauly (2009). "Projecting global marine biodiversity impacts under climate change scenarios.

3. Doney, S.C. (2006). "The Danger of Ocean Acidification. Scientific American 294 (3): 58-65.

4. Emaziye P.O (2013b). Food security index and socio-economic effects of climate change on rural farming households in Delta State, Nigeria. Asian Journal of Agriculture and Rural Development, 3(4): 193-198.

5. Emaziye P.O (2015). The Agricultural implications of climate change factors and their projected future values on rural households in Bayelsa State, Nigeria. International Institute for Science, Technology and Education 5(1): pp. 19-25.

6. Emaziye P.O (2020). Economic Analysis of Co-operative societies and agricultural productivity in rural households in Delta State, Nigeria. International Journal of Agricultural Science, Research and technology in Extension and Education Systems Vol 10(4) pp. 145-148.

7. Emaziye, O. P. (2013a). "Climate change and food security in Niger Delta Region, Nigeria. LAMBERT Academic Publishing Germany - ISBN: $978-3-659-30612-$ 9.

8. Enete, A.A. and Amusa T.A (2010). "Challenges of Agricultural Adaptation to climate change in Nigeria". a synthesis from the literature. Field Actions science Reports. 4.

9. Eurofish International Organization (2020). "Climate change threatens fisheries with immense losses. Eurofish magazine. www.eurofishmagazine.com.

10. FAO (2008a). Food Agricultural Organization. Climate change and food security: a framework document, Rome.

11. Gacia S. (2010). "Food security and Marine captive Fisheries characteristics, trends, drivers and future perspectives 
Emaziye, P.O. Impacts of climate change on fish production among rural fishing households in Delta State, Nigeria.

Philosophical Transactions Biological Sciences 365 (1554): $2869-2880$.

12. Hans-Otto Portner and Myron .A. Peck (2010). Climate change effects on fished and fisheries: Towards a cause-and-effect understanding. Journal of Fish Biology 77(8): 1745-1779

13. Hoeppe P. and E.N. Guenko (2006). "Scientific and Economic Rationales for Innovative Climate Insurance Solution" climate policy $6,607-20$.

14. Ico (2002). International Labour Organisation chapter four. Employment by sector. In key indicator of labour market (K, $\mathrm{Lm}), \quad 5^{\text {th }}$ edition. Available at www.ilo.org/publixation.english.employme nt/srart, dowboa/ki/mo4/pdf.

15. IFAD (2010). International Fund for Agricultural Development Reiterates Negative Impact of Climate Change in Agriculture. http://www.ngrclimatereport.com.

16. International Panel of Climate Change (IPCC), (2007). "Summary for Policymakers in: climate change 2007: Impacts and Adaptation and Vulnerability. Contribution of working group II to the fourth Assessment Report of the Intergovernmental Panel on climate change M.I. Parry et al., (eds) Cambridge University Press, Cambridge U.K and New York, the U.S.A pp 222.

17. IPCC (2007). "Observations: Oceanic climate change and sea level. Fourth
Assessment Report of the Intergovernmental Panel of climate change.

18. Keme, J. (2001). "Assessing the future of Nigeria's economy! Ignored Threats from global climate change www.africaeconomicanalysis.com.

19. National Population Commission (2006). 2006 PHC Priority Tables-National Population Commission. http://www.population.gov.ng

20. Portner, H., R. Krust (2007) "climate change affects marine fishes, through the oxygen Limitation or Thermal Tolerance". Science 315 (5808): 95-97.

21. Wordfish Centre (2006). "The Millennium Development Goats. Fishing for a future: Reducing poverty and hunger by improving fisheries and aquaculture.

22. Ziervogel, G.A., Nyong, B. Osman, C. Conde, S. Cortes and T. Dowing (2006). "Climate Variability and change: Implications for households food security. Assessments of Impacts and Adaptations to climate change (AIACC) Working Paper No. 20, January 2006. The AIACC project office, International START Secretariat, Washington DC, USA.

How to cite this article: Emaziye, P.O. Impacts of climate change on fish production among rural fishing households in Delta State, Nigeria. International Journal of Research and Review. 2021; 8(4): 402-407. DOI: https://doi.org/ 10.52403/ijrr.20210447 